\title{
New U-Th-Pb Isotope Reference Material for SIMS
}

\author{
A. K. Kennedy ${ }^{*}$ \\ *Department of Imaging and Applied Physics, Curtin University, Kent. St., Bentley, \\ 6102, Western Australia, Australia. A.Kennedy@curtin.edu.au
}

Modern geochronology often relies upon SIMS U-Th-Pb micro-analysis, with a spatial resolution of 5-20 microns, to provide age constraints for geological processes recorded by complexly zoned accessory minerals. For example, SIMS U-Th-Pb analysis of the Earths' oldest zircons $(>4.3 \mathrm{Ga}$ ) provides a time line for studies of the early Earth environment [1]. Application of SIMS accessory mineral geochronology to fluid flow in ore deposits, metamorphic P-T-t paths, mass extinctions, tectonics, early Earth atmospheric oxygenation, Lunar evolution etc [2], is driving the development of U-Th- $\mathrm{Pb}$ isotope Reference Material (RM) for zircon, monazite, xenotime, titanite, allanite, apatite, rutile, baddeleyite, cassiterite, opal, perovskite, uraninite etc, within our lab. Our progress in finding and characterising new RM for a group of the above minerals is the topic of this presentation.

Zircon SIMS U-Th-Pb isotope analysis is a comparative method and the accuracy and precision of the results is highly dependent on the quality of the RM [3]. The 520 to 570 Ma Sri Lankan zircons, BR266, G168, G4, and YBr159 are all RM sourced through the World Wide Web (WWW). AusZ2, a 38 Ma gem zircon from eastern Australia (Fig.1a), another WWW gem, appears homogeneous (Fig. 2a) and is currently being characterised. Unfortunately, gem zircons from Afghanistan are heterogeneous. A Pilbara Archaean zircon separate with constant ${ }^{207} \mathrm{~Pb} /{ }^{206} \mathrm{~Pb}$ allows us to assess isotopic mass fractionation [4].

Large faceted gems and crystals of apatite (e.g. Fig 1b). are cheap and readily available through the WWW. Faceted gems have already been assessed for clarity, colour, and size, and this is helpful. Unfortunately, apatite often has very low $U$ and $\mathrm{Th}$, and/or high common $\mathrm{Pb}$, and a large fraction of the material we have examined is unusable as RM. We are currently characterising apatite gems and crystals from Africa, Madagascar, Canada and Brazil that have ages ranging from $420 \mathrm{Ma}$ to $\sim 2060 \mathrm{Ma}$. These apatite have good homogeneity (Fig. 2b), moderate U and Th (100s of ppm) and low common $\mathrm{Pb}$.

The measured SIMS U-Th-Pb age of monazite is a function of the $\mathrm{U}, \mathrm{Th}, \mathrm{Pb}, \mathrm{Y}$, and REE abundances of the monazite [5]. Multiple monazite RM, with a range of compositions, allow calibration schemes that reduce matrix effects [5]. We have purchased four, 5-10 carat faceted gem monazites and four, 1-10 g, monazite crystals. Initial assessment shows these samples are 100 to $900 \mathrm{Ma}$, have $1500-6500 \mathrm{ppm} \mathrm{U}, 6-$ $13 \% \mathrm{Th}$, and most have good isotopic homogeneity. We are lacking a low $\mathrm{U}$, low $\mathrm{Th}$ monazite RM and monazites with compositions along the Huttonite exchange vector.

Titanite from skarns in the Grenville Province of Canada are chemically zoned, and contain mineral inclusions (Fig 1c). This is not ideal for a RM, but these titanite have good isotopic homogeneity in U-Th- $\mathrm{Pb}$ [6] and can be used as a RM for SIMS, as the chemical variation does not produce measurable matrix effects during sputtering. The WWW sourced titanite gems we have are extremely low in U and Th. 
The number of RM needed for $\mathrm{U}-\mathrm{Th}-\mathrm{Pb}$ analysis of a mineral usually reflects the degrees of freedom in the mineral's chemistry and structure. An extreme example of this is the columbite-tantalite $(\mathrm{CT})$ solid solution series $(\mathrm{FeMn})(\mathrm{NbTa})_{2} \mathrm{O}_{6}$ which shows percentage level changes for all elements over very short distances (Fig.1d). We have identified a group of RM for CT, but WDS analysis is essential if U-Th- $\mathrm{Pb}$ age data is to be obtained for this ore mineral.

An ideal SIMS RM must not have significant crystal lattice destruction from radioactive decay. This is a major issue with allanite, as many are metamict. We have identified allanite from Nevada, New Mexico and Australia that not metamict and that range in age from $20 \mathrm{Ma}$ to $1500 \mathrm{Ma}$. Fig. 2c shows data for one Australian allanite.

\section{References}

[1] A. Kemp et al., Earth Planet Sc. Lett. 296 (2010) 45.

[2] F. Poitrasson et al., Chem. Geol. 191 (2002) 3.

[3] L. Nasdala et al., Geostand. Geoanal. Res. 32 (2008) 247.

[4] R. Stern et al., Geostand. Geoanal. Res. 33 (2010) 145.

[5] I. R. Fletcher et al., Chem. Geol. 209 (2004) 295.

[6] A. K. Kennedy, Can. Mineral. 48 (2010) 1423.

[7] This research was supported by NCRIS through the AMMRF and AUSCOPE funding streams.

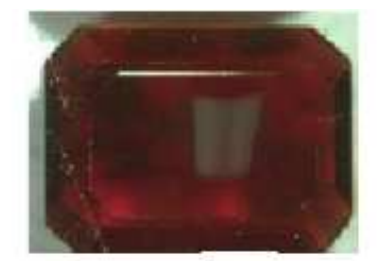

a.

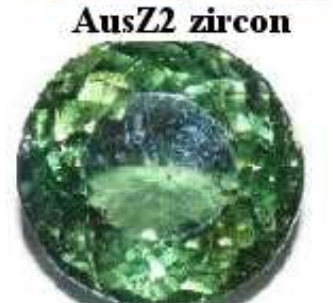

b. Madagascar apatite

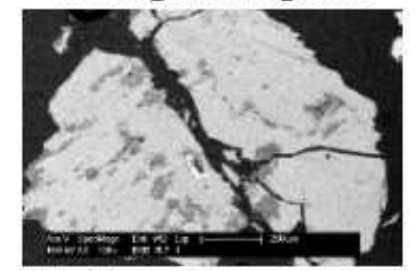

c. Inclusions in titanite

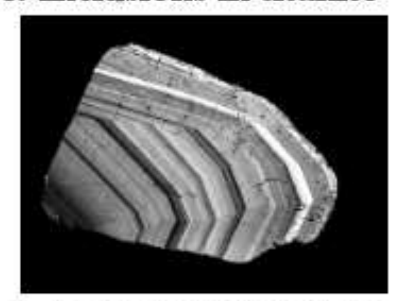

d. Columbite-Tantalite

FIG. 1 Images of RM. a.

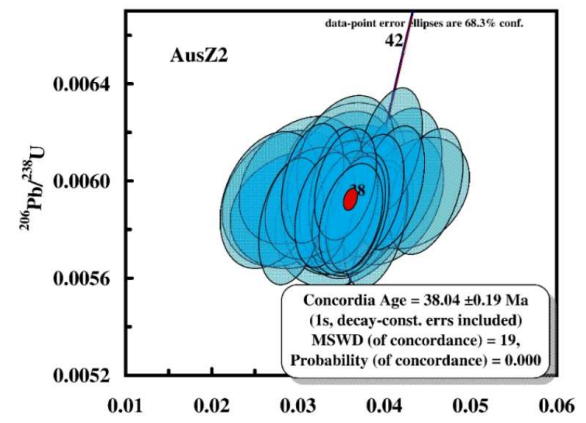

b.

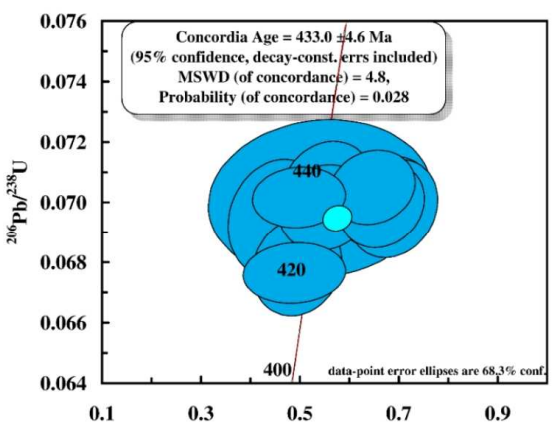

c.

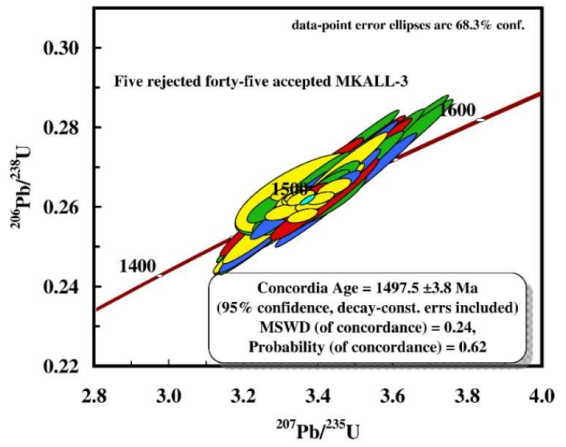

FIG. 2 Concordia diagrams for RM. 